\title{
Esophagogastroduodenoscopy Findings in Patients on the Waiting List for Bariatric Surgery
}

\author{
Cátia Arieira Pedro Boal Carvalho Francisca Dias de Castro José Cotter \\ Gastroenterology Department, Hospital da Senhora da Oliveira, Guimarães, Portugal; Life and Health Sciences \\ Research Institute, School of Medicine, University of Minho, Braga/Guimarães, Portugal; ICVS/3B's, PT Government \\ Associate Laboratory, Braga/Guimarães, Portugal
}

\section{Keywords}

Bariatric surgery · Esophagogastroduodenoscopy · Obesity · Metaplasia $\cdot$ Dysplasia

\section{Abstract}

Background: Bariatric surgery (BS) is one of the most effective approaches to weight loss. Performing esophagogastroduodenoscopy (EGD) prior to BS is controversial but allows the detection and treatment of mucosal lesions that may affect surgical decision and type of surgery. Aim: The aim of this study was to identify the frequency of gastric lesions and Helicobacter pylori ( $\mathrm{Hp}$ ) infection in a group of asymptomatic patients on the waiting list for BS. Methods: This is a retrospective descriptive study including patients undergoing EGD before BS. Results: A total of 360 patients were included with a mean age of $42.1 \pm 10.8$ years, 319 (88.6\%) were females, with a mean body mass index of $42.8 \pm 5.44 \mathrm{~kg} / \mathrm{m}^{2}$. Regarding endoscopic findings, $25.6 \%$ presented no endoscopic lesions, $61.6 \%$ presented hyperemic gastropathy, $11.4 \%$ erosive gastropathy, $1.1 \%$ gastric polyp, and $0.3 \%$ gastric ulcer. Histologically, no changes were observed in $20.8 \%$ of the patients, 239 (66.4\%) presented with superficial gastritis, $11.7 \%(n=42)$ had chronic atrophic gastritis and intestinal metaplasia ( $n=34$ in the antrum, $n=1$ in the body, and $n=7$ in both the antrum and the body), and $1.7 \%(n=6)$ had

\section{KARGER}

E-Mail karger@karger.com www.karger.com/pjg
(C) 2019 Sociedade Portuguesa de Gastrenterologia Published by S. Karger AG, Basel

Karcer

Open access

This article is licensed under the Creative Commons AttributionNonCommercial-NoDerivatives 4.0 International License (CC BYNC-ND) (http://www.karger.com/Services/OpenAccessLicense). Usage and distribution for commercial purposes as well as any distribution of modified material requires written permission. low-grade dysplasia. Hp was positive in 251 (69.7\%) patients. We found that patients with metaplasia or dysplasia were more frequently submitted to surgical techniques that did not exclude the stomach (55.8 vs. $16.4 \%, p<0.001)$. Conclusion: $\mathrm{EGD}$ with histological analysis plays an important role in the pre-surgical evaluation in BS, with a high rate of pathological findings in asymptomatic patients. These findings may have an impact on the long-term management and outcomes of these patients.

C 2019 Sociedade Portuguesa de Gastrenterologia Published by S. Karger AG, Basel

Os achados da endoscopia digestiva alta em doentes em lista de espera para cirurgia bariátrica

\section{Palavras Chave}

Cirurgia bariátrica $\cdot$ Endoscopia digestiva alta . Obesidade $\cdot$ Metaplasia $\cdot$ Displasia

\section{Resumo}

Introdução: A cirurgia bariátrica (CB) constitui uma das abordagens mais eficazes na perda de peso. A realização de endoscopia digestiva alta (EDA) prévia é controversa, podendo contudo detetar ou tratar lesões que podem af- 
etar a decisão cirúrgica e o tipo de cirurgia. Objetivo: Identificar a frequência de lesões gástricas e de infeção por Helicobacter pylori ( $\mathrm{Hp})$ num grupo de doentes assintomáticos em lista para CB. Métodos: Estudo retrospetivo, incluindo doentes submetidos a EDA pré-CB. Resultados: Incluídos 360 doentes com idade média $42.1 \pm 10.8$ anos, 319 (88.6\%) do sexo feminino, com índice massa corporal (IMC) médio $42.8 \pm 5.44 \mathrm{~kg} / \mathrm{m}^{2}$. Relativamente aos achados endoscópicos, $25.6 \%$ não apresentavam alterações, $61.6 \%$ apresentavam gastropatia hiperémica, $11.4 \%$ gastropatia erosiva, $1.1 \%$ pólipos e $0.3 \%$ úlcera gástrica. Histologicamente, $20.8 \%$ não apresentavam alterações histológicas, $239(66.4 \%)$ gastrite superficial, 11.7\% $(n=42)$ gastrite crónica atrófica e metaplasia intestinal ( $n=34$ no antro, $n=1$ no corpo e $n=7$ no corpo e antro) e $1.7 \%$ ( $n=$ 6) apresentavam displasia de baixo grau. $\mathrm{O} \mathrm{Hp}$ era positivo em 251 (69.7\%) doentes. Verificamos que doentes com displasia ou metaplasia foram submetidos mais frequentemente a técnicas cirúrgicas que não excluíam o estômago (55.8 vs. $16.4 \%, p<0.001)$. Conclusão: A EDA com biópsias gástricas tem um papel importante na avaliação préCB com uma taxa elevada de achados patológicos em doentes assintomáticos. Estes achados podem condicionar a monitorização e os outcomes destes doentes.

( 2019 Sociedade Portuguesa de Gastrenterologia Publicado por S. Karger AG, Basel

\section{Introduction}

Obesity, defined as a body mass index (BMI) $\geq 30 \mathrm{~kg} /$ $\mathrm{m}^{2}$, is a worldwide public health concern. In the last decades, the worldwide prevalence of obesity has nearly doubled, currently ranging from 7 to $15 \%$ in developed countries [1]. A World Health Organization study predicts that in 2020, in Portugal, $21 \%$ of men and $22 \%$ of women will be obese [2]. This epidemic pathology is a chronic, relapsing and multifactorial disease, and its treatment requires a continuum of multidisciplinary care models ranging from lifestyle and nutritional changes to pharmacological treatment and surgery [3].

Although bariatric surgery (BS) is the most clinically effective treatment for severe obesity, with sustainable weight loss and obesity-related comorbidity improvement, this procedure is associated with significant risks $[3,4]$, such as bleeding $[5,6]$, stenosis of anastomosis $[7$, $8]$, and bariatric leaks [9].

The surgical techniques currently most frequently performed are sleeve gastrectomy, where part of the great curvature is removed leaving a tubularized conduit based on the lesser curvature; gastric bypass, which results in the creation of a gastric pouch anastomosed to a roux limb of the mid-jejunum, with the remaining stomach left in situ; and single anastomosis duodeno-ileal bypass with sleeve gastrectomy (SADI-S), where a sleeve gastrectomy is performed followed by an end-to-side duodeno-ileal diversion [10]. Their weight loss mechanisms are not completely understood but include restrictive, malabsorptive, and metabolic components $[10,11]$.

In recent years, an association between obesity and a variety of gastrointestinal disorders has been documented, such as gastroesophageal reflux disease, erosive esophagitis, hiatal hernia, Barrett's esophagus, esophageal adenocarcinoma, and Helicobacter pylori $(\mathrm{Hp})$ infection [12-15].

The role of routine esophagogastroduodenoscopy (EGD) before BS in asymptomatic patients remains a hot topic and a controversial issue [1]. Nevertheless, it allows the determination of $\mathrm{Hp}$ infection status and the timely detection, assessment, and management of significant gastric pathology, including peptic ulcer disease and premalignant lesions [1]. The aim of this study is to identify the frequency of relevant gastric abnormalities and $\mathrm{Hp}$ infection in a group of asymptomatic obese patients that were referred to BS.

\section{Methods}

We performed a retrospective descriptive study including asymptomatic patients undergoing EGD before BS between 2012 and 2016 at the Hospital da Senhora da Oliveira, Guimarães, Portugal. In all patients, EGD was performed with random endoscopic biopsies (minimum 2 from the antrum, 1 from the incisura, and 2 from the corpus) [16] that were fixed in a solution of formaldehyde, and the presence of $\mathrm{Hp}$ was investigated by immunohistochemistry. All patients on proton pump inhibitors suspended treatment at least 15 days before EGD.

Information was collected by reviewing medical records regarding demographics (age, gender, and BMI) and comorbid conditions (hypertension, osteoarticular pathology, dyslipidemia, type 2 diabetes, and obstructive sleep apnea). Endoscopic and histological findings were assessed, as well as the type of surgery performed.

Statistical analysis was performed with SPSS ${ }^{\circledR}$ version 22.0 (IBM, Armonk, NY, USA). The categorical variables were presented as frequencies and percentages, and continuous variables as means and standard deviations. All reported $p$ values are twotailed, with a $p$ value of 0.05 indicating statistical significance. The differences between categorical variables were evaluated by $\chi^{2}$ test and quantitative variables by independent samples $t$ test. During data collection and statistical analysis, anonymity was ensured. 


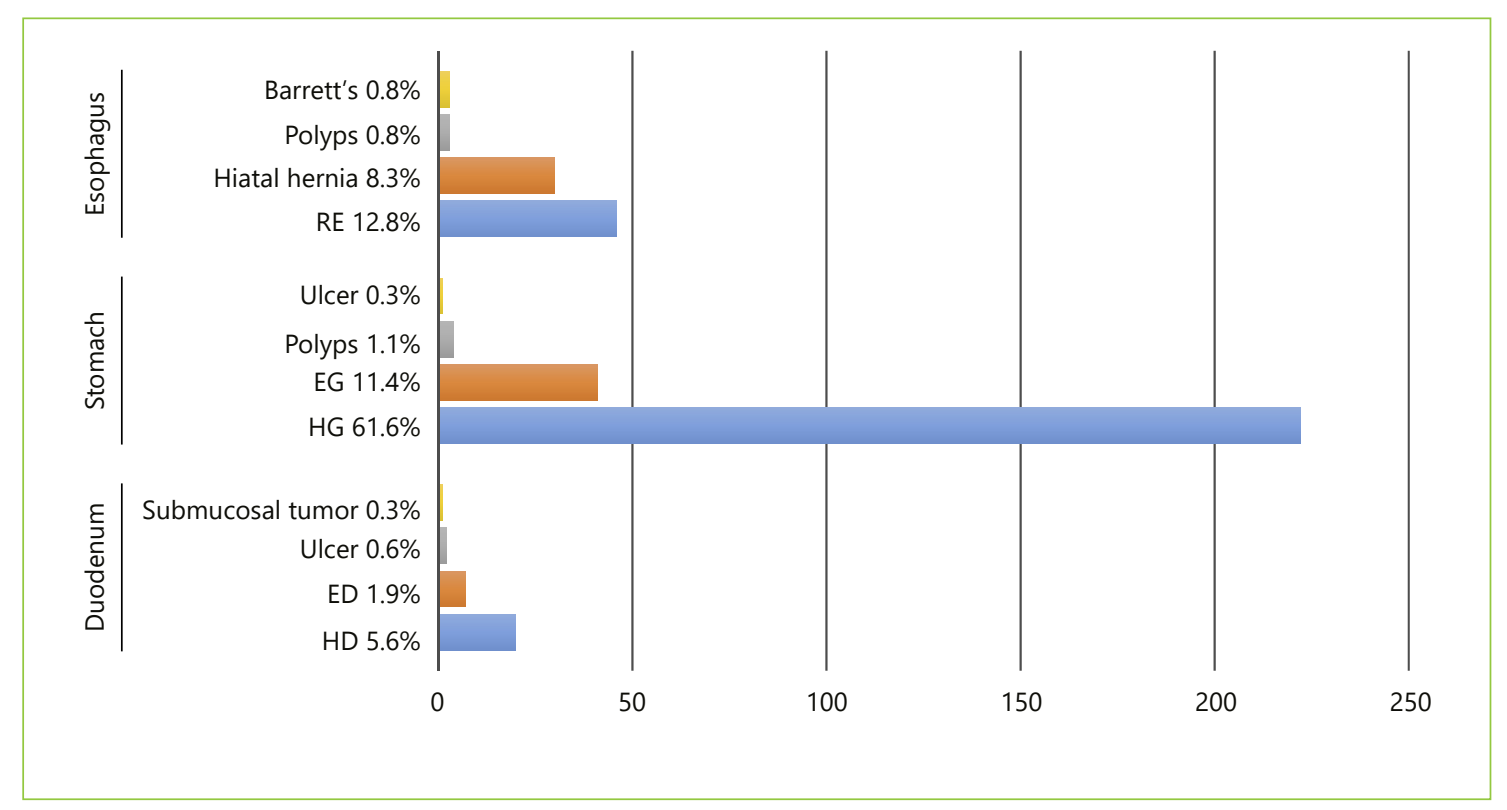

Fig. 1. Esophagogastroduodenoscopy findings. EG, erosive gastropathy; ED, erosive duodenopathy; HG, hyperemic gastropathy; HD, hyperemic duodenopathy; RE, reflux esophagitis.

\section{Results}

This study included 360 asymptomatic patients with a mean age of $42.1 \pm 10.8$ years, $319(88.6 \%)$ were females, with a mean BMI of $42.8 \pm 5.44 \mathrm{~kg} / \mathrm{m}^{2}$. The mean followup was $17.7 \pm 10.1$ months. BMI $\geq 40 \mathrm{~kg} / \mathrm{m}^{2}$ was present in $70.3 \%$ of the patients, $27.8 \%$ had a BMI between 35 and $39.9 \mathrm{~kg} / \mathrm{m}^{2}$, and $1.9 \%$ a BMI between 30 and $34.9 \mathrm{~kg} / \mathrm{m}^{2}$.

At least 1 comorbidity associated with overweight was present in 70.6\%: $41.9 \%$ had hypertension, $33.9 \%$ osteoarticular pathology, $21.4 \%$ dyslipidemia, $15.3 \%$ type 2 diabetes, and $7.2 \%$ obstructive sleep apnea (Table 1). Seven patients were on proton pump inhibitors because they were simultaneously medicated with acetylsalicylic acid.

No lesions were observed in the esophagus in $85.6 \%$; $12.8 \%$ had reflux esophagitis, $0.8 \%$ esophageal polyps, and $0.8 \%$ Barrett's esophagus. Hiatal hernia was diagnosed in $30(8.3 \%)$ patients.

Regarding gastric endoscopic findings, $25.6 \%$ presented with no endoscopic lesions, $61.6 \%$ presented with hyperemic gastropathy, $11.4 \%$ with erosive gastropathy, $1.1 \%$ with gastric polyp, and $0.3 \%$ with gastric ulcer. Concerning the duodenum, no lesions were observed in $91.7 \%$ of the patients, $5.6 \%$ presented with hyperemic duodenopathy, $1.9 \%$ with erosive duodenopathy, $0.6 \%$ with duodenal ulcer, and $0.3 \%$ with submucosal tumor. EGD findings are summarized in Figure 1.

Importance of EGD Evaluation prior to Bariatric Surgery
Table 1. Characteristics of the population $(n=360)$

\begin{tabular}{lc}
\hline Gender & \\
$\quad$ Male & $41(11.4)$ \\
$\quad$ Female & $319(88.6)$ \\
Age, years & $42.1 \pm 10.8$ \\
BMI, kg/m² & $42.8 \pm 5.44$ \\
BMI & \\
$\quad 30-34.9 \mathrm{~kg} / \mathrm{m}^{2}$ & $7(1.9)$ \\
$35-39.9 \mathrm{~kg} / \mathrm{m}^{2}$ & $100(27.8)$ \\
$\geq 40 \mathrm{~kg} / \mathrm{m}^{2}$ & $253(70.3)$ \\
\hline Follow-up, months & $17.7 \pm 10.1$ \\
Comorbidities & $151(41.9)$ \\
$\quad$ Hypertension & $122(33.9)$ \\
$\quad$ Osteoarticular pathology & $77(21.4)$ \\
$\quad$ Dyslipidemia & $55(15.3)$ \\
Type 2 diabetes & $26(7.2)$ \\
$\quad$ Obstructive sleep apnea &
\end{tabular}

Values are $n(\%)$ or means \pm standard deviations. BMI, body mass index.

Histologically, 251 (69.7\%) patients were Hp positive (Table 2). There were no statistical differences regarding age ( 41.3 vs. 44.0 years, $p=0.132$; df 358 ) or BMI ( 42.9 vs. $42.9, p=0.601$; df 358) for Hp infection status.

In Table 3, the prevalence of endoscopic lesions regarding Hp status is shown. We observed that Hp-posi- 
Table 2. Histopathological examination of gastric biopsies

\begin{tabular}{lcc}
\hline & $n(\%)$ & $95 \%$ CI \\
\hline Helicobacter pylori positive & $251(69.7)$ & $65-74.7$ \\
Superficial gastritis & $239(66.4)$ & $61.4-71.4$ \\
Chronic atrophic gastritis or & & \\
intestinal metaplasia & $42(11.7)$ & $8.2-15$ \\
Low-grade dysplasia & $6(1.7)$ & $0.6-3.4$ \\
High-grade dysplasia & $0(0.0)$ & - \\
\hline
\end{tabular}

CI, confidence interval.

Table 3. Presence of EGD findings regarding Hp status

\begin{tabular}{lccl}
\hline & $\mathrm{Hp}+$ & $\mathrm{Hp}-$ & $\mathrm{p}$ \\
\hline Reflux esophagitis & $24(9.7)$ & $22(20.8)$ & $0.005^{*}$ \\
Esophageal polyps & $1(0.4)$ & $1(0.9)$ & $\mathrm{ns}$ \\
Barrett's esophagus & $2(0.8)$ & $1(0.9)$ & $\mathrm{ns}$ \\
Esophageal polyps & $0(0.0)$ & $1(0.9)$ & $\mathrm{ns}$ \\
Hiatal hernia & $20(8)$ & $10(9.2)$ & $\mathrm{ns}$ \\
Hyperemic gastropathy & $161(64.1)$ & $61(56)$ & $\mathrm{ns}$ \\
Erosive gastropathy & $27(10.8)$ & $14(12.8)$ & $\mathrm{ns}$ \\
Polyps & $2(0.8)$ & $2(1.8)$ & $\mathrm{ns}$ \\
Gastric ulcer & $1(0.4)$ & $0(0.0)$ & $\mathrm{ns}$ \\
Hyperemic duodenopathy & $16(6.5)$ & $4(3.9)$ & $\mathrm{ns}$ \\
Erosive duodenopathy & $2(0.8)$ & $5(4.5)$ & $\mathrm{ns}$ \\
Duodenal ulcer & $0(0.0)$ & $2(1.8)$ & $\mathrm{ns}$ \\
Submucosal tumor & $1(0.4)$ & $0(0.0)$ & $\mathrm{ns}$ \\
\hline
\end{tabular}

Values are $n$ (\%). EGD, esophagogastroduodenoscopy; Hp, Helicobacter pylori; ns, nonsignificant $(p>0.05) .{ }^{*}$ Statistically significant $(p<0.05)$.

tive patients less frequently had erosive esophagitis (9.7 vs. $20.8 \%, p=0.005$ ).

In $20.8 \%$ of the patients, no histological changes were observed, while 239 (66.4\%) presented with superficial gastritis, $11.7 \%(n=42)$ presented with chronic atrophic gastritis and intestinal metaplasia $(n=34$ in the antrum, $n=1$ in the body, and $n=7$ in both the body and the antrum), and $1.7 \%(n=6)$ had low-grade dysplasia without visible lesions (Table 2). Regarding Hp infection with premalignant histology in the 42 patients with chronic atrophic gastritis and intestinal metaplasia, $62.8 \%$ were $\mathrm{Hp}$ positive, and from the 6 patients with low-grade dysplasia, $50 \%$ presented $\mathrm{Hp}$ infection. There were no statistical differences regarding age ( 49.3 vs. 41.1 years, $p=0.388$; df 358 ) or BMI (43.4 vs. $42.8, p=0.516$; df 358 ) for the prevalence of a premalignant histology. Patients with a premalignant histology more frequently had diabetes (32.6 vs. $12.9 \%, p=0.001$ ).

There were no reported complications in EGD due to the endoscopic procedure or due to anesthesia when the procedure was done under sedation.

In $78.9 \%(n=284)$ of the patients, a gastric bypass was performed, $17.5 \%(n=63)$ were submitted to sleeve technique, and in $3.6 \%(n=13)$ SADI-S was the surgery executed. All types of surgery were performed by laparoscopy.

We found that patients with gastric dysplasia or metaplasia were more frequently submitted to surgical techniques that did not exclude the stomach, such as sleeve or SADI-S (55.8 vs. $16.4 \%, p<0.001$; OR 6.44; $95 \%$ CI 3.29$12.60)$, in particular the 14 patients with extensive chronic atrophic gastritis/intestinal metaplasia and low-grade dysplasia were submitted to sleeve or SADI-S.

\section{Discussion}

This study focuses on several important issues, reporting high rates of abnormal findings on endoscopy and histopathology in asymptomatic patients in whom routine EGD prior to BS was performed. In the preoperative workup of patients scheduled for BS, EGD with routine biopsies plays an important role in the diagnosis of pathological conditions [17-24]. It offers the advantage of visualizing esophageal, gastric, and duodenal mucosa, with assessment of Hp status infection and its possible inflammatory and neoplastic complications [17-24]. The detection of histological premalignant conditions or lesions with potential progression to malignancy may compromise the medical and surgical management of these patients [18-24].

However, performing routine EGD at this point is still controversial. While the European Association for Endoscopic Surgery recommends it in all patients [17], the Society of American Gastrointestinal and Endoscopic Surgeons (SAGES) advocates EGD only in symptomatic patients as long as their major concern is related to surgical outcomes and immediate postoperative complications, including marginal ulcers [25]. The rationale for performing EGD before BS and our biggest concern is to avoid the negative long-term $\mathrm{Hp}$ complications in a young and asymptomatic population, namely the association with peptic ulcer disease and gastric cancer [26, 27].

In our series in a Portuguese population, the frequency of $\mathrm{Hp}$ infection was nearly $70 \%$. Our results show a 
higher frequency of $\mathrm{Hp}$ infection than previous studies performed in morbidly obese individuals in other countries, such as America and China [28-30]. Although in the last decades a worldwide decrease in the prevalence of $\mathrm{Hp}$ infection has been reported in parallel with an improvement in socioeconomic conditions, Portugal remains one of the countries with the highest rates of $\mathrm{Hp}$ infection in Europe with a prevalence around 84\% [31] as opposed to Northern America [32,33]. In addition, $\mathrm{Hp}$ is recognized as a type I carcinogen and drives the Correa cascade, a multistep pathway with sequential progression from normal gastric mucosa through chronic gastritis, chronic atrophic gastritis, and intestinal metaplasia to dysplasia and ultimately gastric adenocarcinoma [34]. It is estimated that $89 \%$ of noncardia gastric cancers are attributed to chronic Hp infection [35]. Atrophic gastritis, intestinal metaplasia, and low- and high-grade dysplasia have an annual risk of cancer progression of $0.8,1.8,3.9$, and $32.4 \%$, respectively [36]. Moreover, the histological characterization of gastric mucosa previous to BS might be an important step to establish the subsequent surgical strategy.

Data on the epidemiology of premalignant gastric lesions in an asymptomatic population are scarce. According to a population-based study performed in 2011, in 9.3\% of asymptomatic subjects signs of premalignant gastric lesions were found, and these lesions were more frequent in older patients ( $>60$ years) [37]. In line with these results, in our cohort, 42 patients (corresponding to more than $10 \%$ of this asymptomatic population) presented with chronic atrophic gastritis and intestinal metaplasia, and $1.7 \%$ presented with low-grade dysplasia. However, in our cohort, these premalignant findings were present in younger patients (mean age: 41.1 years) with a greater predisposition for progression and development of gastric cancer given the recent association between overweight, obesity, and gastric cancer [38-40]. Patients with extensive atrophy/metaplasia and with dysplasia $(n=14)$ are optimal candidates to benefit from an endoscopic gastric surveillance according to the European Society of Gastrointestinal Endoscopy (ESGE) guidelines with intervals of no more than 3 years for extensive atrophic gastritis and intestinal metaplasia and no more than 12 months for low-grade dysplasia. Patients with high-grade dysplasia should undergo staging and adequate management [41], reinforcing the importance of alternative strategies performed in BS that do not exclude the stomach.

In agreement with these findings, we also observed in our population that patients with these abnormal histological findings were more frequently submitted to BS techniques that did not exclude the stomach, to allow future adequate surveillance of gastric mucosa and avoid development of cancer arising in gastric excluded mucosa as described in some clinical reports [42, 43]. Besides, the importance of preoperative EGD is also supported by Sharaf et al. [24] who found that $90 \%$ of their patients had at least 1 relevant lesion, with $60 \%$ delaying or even changing the clinical approach. Similarly, other investigators have stated the same results, corroborating and reinforcing the importance of routine EGD before BS [19-23].

Since gastric cancer is the third leading cause of cancer mortality [44] and Portugal has the highest rates in Western Europe [45], and since gastric cancer has recognized carcinogenic factors and specific precursor lesions, screening for the identification of patients with these lesions and their surveillance result in a lower incidence of and mortality from gastric cancer [41].

\section{Conclusion}

Obesity is a major epidemiologic challenge that will be increasing and is a matter of concern in clinical practice [3]. In view of our results, and despite all the controversies, we strongly recommend a nonselective EGD screening in patients referred to BS. We report, in an asymptomatic population, a relevant frequency of potential gastric lesions that may progress to gastric cancer and that will benefit from screening and surveillance in gastric cancer programs. Moreover, EGD allows, at the same time, the assessment of $\mathrm{Hp}$ infection status, which is a recognized oncogenic bacterium with an imperative indication for eradication [35]. After routine EGD, Hp-positive patients should undergo eradication, and the urea breath test should be used for Hp post-treatment assessment [46].

With this in mind, in these patients, routine EGD prior to BS should be seriously considered not only to avoid postoperative complications but also to guide surgical decision and possible surveillance. Further prospective studies with a larger sample size are needed to corroborate our findings and to identify the consequences of inaccessibility of the excluded stomach.

\section{Statement of Ethics}

The authors have no ethical conflicts to disclose. 


\section{References}

1 De Palma GD, Forestieri P. Role of endoscopy in the bariatric surgery of patients. World J Gastroenterol. 2014 Jun;20(24):7777-84.

2 World Health Organization. WHO Global Health Observatory Data Repository. 2013. Available from: http://www.euro.who.int/ data/assets/pdf_file/0003/243318/PortugalWHO-Country-Profile.pdf

3 Heymsfield SB, Wadden TA. Mechanisms, Pathophysiology, and Management of Obesity. N Engl J Med. 2017 Jan;376(3):254-66.

4 Pories WJ. Bariatric surgery: risks and rewards. J Clin Endocrinol Metab. 2008 Nov; 93(11 Suppl 1):S89-96.

5 Bakhos C, Alkhoury F, Kyriakides T, Reinhold R, Nadzam G. Early postoperative hemorrhage after open and laparoscopic roux-eny gastric bypass. Obes Surg. 2009 Feb;19(2): 153-7.

6 Nguyen NT, Rivers R, Wolfe BM. Early gastrointestinal hemorrhage after laparoscopic gastric bypass. Obes Surg. 2003 Feb;13(1):625.

7 Rosenthal RJ. Dilating the stenotic gastrojejunostomy after laparoscopic Roux-en-Y gastric bypass for morbid obesity: when things go wrong. J Gastrointest Surg. 2009 Sep;13(9): 1561-3.

8 Parikh A, Alley JB, Peterson RM, Harnisch MC, Pfluke JM, Tapper DM, et al. Management options for symptomatic stenosis after laparoscopic vertical sleeve gastrectomy in the morbidly obese. Surg Endosc. 2012 Mar; 26(3):738-46.

9 Aurora AR, Khaitan L, Saber AA. Sleeve gastrectomy and the risk of leak: a systematic analysis of 4,888 patients. Surg Endosc. 2012 Jun;26(6):1509-15.

10 Vu L, Switzer NJ, De Gara C, Karmali S. Surgical interventions for obesity and metabolic disease. Best Pract Res Clin Endocrinol Metab. 2013 Apr;27(2):239-46.

11 O'Brien P. Surgical Treatment of obesity. In: De Groot LJ, Chrousos G, Dungan K, et al., editors. Endotext [Internet]. South Dartmouth (MA): MDText.com, Inc.; 2000.

12 Carabotti M, D'Ercole C, Iossa A, Corazziari E, Silecchia G, Severi C. Helicobacter pylori infection in obesity and its clinical outcome after bariatric surgery. World J Gastroenterol. 2014 Jan;20(3):647-53.

13 Nilsson M, Johnsen R, Ye W, Hveem K, Lagergren J. Obesity and estrogen as risk factors for gastroesophageal reflux symptoms. JAMA. 2003 Jul;290(1):66-72.
14 Stein DJ, El-Serag HB, Kuczynski J, Kramer JR, Sampliner RE. The association of body mass index with Barrett's oesophagus. Aliment Pharmacol Ther. 2005 Nov;22(10): 1005-10.

15 Wilson LJ, Ma W, Hirschowitz BI. Association of obesity with hiatal hernia and esophagitis. Am J Gastroenterol. 1999 Oct;94(10): $2840-4$.

16 Stolte M, Meining A. The updated Sydney system: classification and grading of gastritis as the basis of diagnosis and treatment. Can J Gastroenterol. 2001 Sep;15(9):591-8.

17 Sauerland S, Angrisani L, Belachew M, Chevallier JM, Favretti F, Finer N, et al.; European Association for Endoscopic Surgery. Obesity surgery: evidence-based guidelines of the European Association for Endoscopic Surgery (EAES). Surg Endosc. 2005 Feb;19(2):200-21.

18 Abd Ellatif ME, Alfalah H, Asker WA, El Nakeeb AE, Magdy A, Thabet W, et al. Place of upper endoscopy before and after bariatric surgery: A multicenter experience with 3219 patients. World J Gastrointest Endosc. 2016 May;8(10):409-17.

19 Assef MS, Melo TT, Araki O, Marioni F. Evaluation of upper gastrointestinal endoscopy in patients undergoing bariatric surgery. Arq Bras Cir Dig. 2015 Dec;28(Suppl 1):39-42.

20 Csendes A, Burgos AM, Smok G, Beltran M. Endoscopic and histologic findings of the foregut in 426 patients with morbid obesity. Obes Surg. 2007 Jan;17(1):28-34.

21 de Moura Almeida A, Cotrim HP, Santos AS, Bitencourt AG, Barbosa DB, Lobo AP, et al. Preoperative upper gastrointestinal endoscopy in obese patients undergoing bariatric surgery: is it necessary? Surg Obes Relat Dis. 2008 Mar-Apr;4(2):144-9; discussion 150-1.

22 Küper MA, Kratt T, Kramer KM, Zdichavsky M, Schneider JH, Glatzle J, et al. Effort, safety, and findings of routine preoperative endoscopic evaluation of morbidly obese patients undergoing bariatric surgery. Surg Endosc. 2010 Aug;24(8):1996-2001.

23 Muñoz R, Ibáñez L, Salinas J, Escalona A, Pérez G, Pimentel F, et al. Importance of routine preoperative upper GI endoscopy: why all patients should be evaluated? Obes Surg. 2009 Apr;19(4):427-31.

24 Sharaf RN, Weinshel EH, Bini EJ, Rosenberg J, Sherman A, Ren CJ. Endoscopy plays an important preoperative role in bariatric surgery. Obes Surg. 2004 Nov-Dec;14(10):1367-72.
25 Evans JA, Muthusamy VR, Acosta RD, Bruining $\mathrm{DH}$, Chandrasekhara V, Chathadi KV, et al.; American Society for Gastrointestinal Endoscopy Standards of Practice Committee. The role of endoscopy in the bariatric surgery patient. Gastrointest Endosc. 2015 May; 81(5):1063-72.

26 Liu KS, Wong IO, Leung WK. Helicobacter pylori associated gastric intestinal metaplasia: treatment and surveillance. World J Gastroenterol. 2016 Jan;22(3):1311-20.

27 Watari J, Chen N, Amenta PS, Fukui H, Oshima T, Tomita T, et al. Helicobacter pylori associated chronic gastritis, clinical syndromes, precancerous lesions, and pathogenesis of gastric cancer development. World J Gastroenterol. 2014 May;20(18):5461-73.

28 Erim T, Cruz-Correa MR, Szomstein S, Velis E, Rosenthal R. Prevalence of Helicobacter pylori seropositivity among patients undergoing bariatric surgery: a preliminary study. World J Surg. 2008 Sep;32(9):2021-5.

29 Lee J, Wong SK, Liu SY, Ng EK. Is Preoperative Upper Gastrointestinal Endoscopy in Obese Patients Undergoing Bariatric Surgery Mandatory? An Asian Perspective. Obes Surg. 2017 Jan;27(1):44-50.

30 Verma S, Sharma D, Kanwar P, Sohn W, Mohanty SR, Tortolani AJ, et al. Prevalence of Helicobacter pylori infection in bariatric patients: a histologic assessment. Surg Obes Relat Dis. 2013 Sep-Oct;9(5):679-85.

31 Bastos J, Peleteiro B, Barros R, Alves L, Severo $M$, de Fátima Pina $M$, et al. Sociodemographic determinants of prevalence and incidence of Helicobacter pylori infection in Portuguese adults. Helicobacter. 2013 Dec;18(6):413-22.

32 Eusebi LH, Zagari RM, Bazzoli F. Epidemiology of Helicobacter pylori infection. Helicobacter. 2014 Sep;19 Suppl 1:1-5.

33 Hooi JKY, Lai WY, Ng WK, Suen MMY, Underwood FE, Tanyingoh D, et al. Global Prevalence of Helicobacter pylori Infection: Systematic Review and Meta-Analysis. Gastroenterology. 2017 Aug;153(2):420-429.

34 Moss SF. The Clinical Evidence Linking Helicobacter pylori to Gastric Cancer. Cell Mol Gastroenterol Hepatol. 2016 Dec;3(2):18391.

35 Sugano K, Tack J, Kuipers EJ, Graham DY, El-Omar EM, Miura S, et al.; faculty members of Kyoto Global Consensus Conference. Kyoto global consensus report on Helicobacter pylori gastritis. Gut. 2015 Sep;64(9):1353-67. 
36 de Vries AC, van Grieken NC, Looman CW, Casparie MK, de Vries E, Meijer GA, et al. Gastric cancer risk in patients with premalignant gastric lesions: a nationwide cohort study in the Netherlands. Gastroenterology. 2008 Apr;134(4):945-52.

37 den Hoed CM, van Eijck BC, Capelle LG, van Dekken H, Biermann K, Siersema PD, et al. The prevalence of premalignant gastric lesions in asymptomatic patients: predicting the future incidence of gastric cancer. Eur J Cancer. 2011 May;47(8):1211-8.

38 Yang P, Zhou Y, Chen B, Wan HW, Jia GQ, Bai HL, et al. Overweight, obesity and gastric cancer risk: results from a meta-analysis of cohort studies. Eur J Cancer. 2009 Nov;45(16): 2867-73.

39 Li Q, Zhang J, Zhou Y, Qiao L. Obesity and gastric cancer. Front Biosci. 2012 Jun;17(7): 2383-90.
40 Garai J, Uddo RB, Mohler MC, Pelligrino N, Scribner R, Sothern MS, et al. At the crossroad between obesity and gastric cancer. Methods Mol Biol. 2015;1238:689-707.

41 Dinis-Ribeiro M, Areia M, de Vries AC, Marcos-Pinto R, Monteiro-Soares M, O'Connor A, et al. Management of precancerous conditions and lesions in the stomach (MAPS): guideline from the European Society of Gastrointestinal Endoscopy (ESGE), European Helicobacter Study Group (EHSG), European Society of Pathology (ESP), and the Sociedade Portuguesa de Endoscopia Digestiva (SPED). Endoscopy. 2012 Jan;44(1):74-94.

42 Trincado MT, del Olmo JC, García Castaño J, Cuesta C, Blanco JI, Awad S, et al. Gastric pouch carcinoma after gastric bypass for morbid obesity. Obes Surg. 2005 Sep;15(8): 1215-7.
43 Babor R, Booth M. Adenocarcinoma of the gastric pouch 26 years after loop gastric bypass. Obes Surg. 2006 Jul;16(7):935-8.

44 Ferlay J, Soerjomataram I, Dikshit R, Eser S, Mathers C, Rebelo M, et al. Cancer incidence and mortality worldwide: sources, methods and major patterns in GLOBOCAN 2012. Int J Cancer. 2015 Mar; 136(5):E359-86.

45 Morais S, Ferro A, Bastos A, Castro C, Lunet $\mathrm{N}$, Peleteiro B. Trends in gastric cancer mortality and in the prevalence of Helicobacter pylori infection in Portugal. Eur J Cancer Prev. 2016 Jul;25(4):275-81.

46 Malfertheiner P, Megraud F, O’Morain CA, Gisbert JP, Kuipers EJ, Axon AT, et al.; European Helicobacter and Microbiota Study Group and Consensus panel. Management of Helicobacter pylori infection-the Maastricht V/Florence Consensus Report. Gut. 2017 Jan; 66(1):6-30. 